\title{
Correspondence
}

\begin{abstract}
Section 136
DeAr SIRS

In the light of Rassaby and Roger's paper on "Psychiatric referrals from the police..." (Bulletin, March 1987) our interpretation of Section 136 may be of interest. These thoughts came out of discussions as to how we could best, and most legally, cope with a move to stop patients detained under Section 136 being taken direct to a distant mental hospital. Assessment was to take place in the Accident and Emergency Department of the local DGH (Charing Cross) which also has a Psychiatric Department.
\end{abstract}

During the course of the discussions two aspects became clearer.

(1) The act quite clearly states that the person is being detained "For the purpose of enabling him to be examined by a registered medical practitioner and to be interviewed by an approved social worker and of making any necessary arrangements for his treatment or care" (our emphasis). It seemed good practice that this should if possible be a joint assessment, that it should occur as soon as possible, and that "Arrangements for his treatment and care" implied more than merely deciding whether to admit or not. A further implication seems to be that once this joint assessment had been made, powers to detain under Section 136 are void and that any further compulsory detention would have to be under Section 2 or 4 of the Mental Health Act, except in those very rare circumstances where the doctor and social worker felt a further period of assessment was necessary before they could decide what needed to happen to the patient.

(2) It seemed to us that there is a clear administrative distinction between detention in a place of safety and admission to hospital. The patient is detained at the hospital in the Accident and Emergency Department. At times they may need to be admitted to the psychiatric ward because they are not containable in the Accident and Emergency Department. This is a separate decision and again, once the joint assessment has been made, further detention, if necessary, would be under other sections of the Mental Health Act.

The practical significance of this is that the local duty Approved Social Worker has to come in to assess such patients. The positive result is that decisions are taken much more quickly, reducing unnecessary detention to a minimum; there is a joint psycho-social assessment rather than merely a medical one and thus, hopefully, the consideration of a wider range of options than just to detain or not. We believe the patients involved get a better service.

SAM BAXTER

Consultant Psychiatrist John ChamberLaIN

Charing Cross Hospital (Fulham)

Group Principal Social Worker

London W6

\section{Community psychiatry!}

\section{Dear Marge}

I am in a desperate state-can you help me? I'm 32, and over the past two years, since I became a consultant, I've fallen victim to the charismatic religious cult called 'Community Psychiatry'. Their followers are nicknamed 'Loonies' (derived from the Latin word for 'Moonies'), and now I am one.

Typically it started in a small way, and I thought I could handle it. But, after weeks of brainwashing, which they called 'normalisation', I felt so virtuous, so good, so modern, ... so smug.

At weekends I went to religious meetings called 'workshops'. The congregation was composed of people from all professions. There were doctors, nurses, clinical psychologists, social workers, and many other ageing hippies.

The religion is quite simple really, and is probably why it is so seductive. Basically, all that is good is in the 'community' (heaven), and all that is evil is in 'hospital' (hell). Our churches are called Community Mental Health Centres, and they are open to anyone, without the need of a referral letter. Unfortunately, they are not open after 5 or at the weekends, so if anyone needs help at these times, they can go to Hell (sorry hospital).

Our commandments are these:

(1) Though shalt not speak in clear terms, but instead use words like 'needs', 'enable', 'catalyse', 'facilitate', and 'restructure'. Remember, in psychiatric politics the Word is mightier than the meaning.

(2) Thou shalt not use science. 'Community Psychiatry' needs only faith, not proof.

(3) Thou shalt not covet thy consultant's power, nor his salary, nor his office, nor his Volvo.

(4) Thou shalt not commit adultery (except during a residential psychotherapy workshop).

(5) Thou shalt not utter the words 'illness' or 'patient'.

(6) Thou shalt use less drugs and ECT. This would prove that 'community psychiatry' is better than hospitals.

As a disciple, I was charged with the task of spreading the Word. Our work has been made easier by some disciples joining the Health Advisory Service and the Mental Health Act Commission. Daily, I prayed for the courage I needed to preach to evil and obdurate colleagues, but unfortunately many of them (including Professors, who should know better) remain unrepentant. After a while I found myself talking in a strange language, calling patients 'consumers', 'users', or 'clients', quite indiscriminately. Eventually, I couldn't think for myself, without a multidisciplinary team around me to facilitate and catalyse my helping skills. All my 12 years of medical education suddenly seemed irrelevant. I became very confused. Was I in a 'beehive' or a 'network'? Was I a key-worker, a drone, a Queen, a catalyst, a resource, or what? What were my individual needs? All these questions whirled around my head - my role had become completely blurred. I was completely cognitively destructured. 